Harvard Kennedy School Misinformation Review ${ }^{1}$

March 2021, Volume 1, Special Issue on US Elections and Disinformation

Creative Commons Attribution 4.0 International (CC BY 4.0)

Reprints and permissions: misinforeview@hks.harvard.edu

DOI: https://doi.org/10.37016/mr-2020-58

Website: misinforeview.hks.harvard.edu

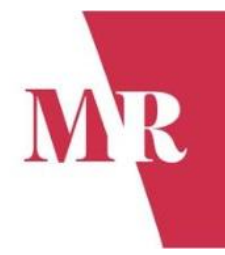

\title{
COVID-19 disinformation and political engagement among communities of color: The role of media literacy
}

Communities of color, suffering equity gaps and disproportionate COVID-19 effects, also must resist ongoing disinformation campaigns designed to impede their political influence. A representative, national survey $(N=1264)$ of adults conducted June-July 2020 found that nonwhite respondents tended to report less COVID-19 knowledge, media literacy, and voting intent than white respondents, but more acceptance of COVID-19 disinformation and for risks associated with protesting for social justice. General media literacy skills are associated with COVID-19 knowledge and political engagement, while science media literacy is associated with less acceptance of COVID-19 disinformation. Media literacy skills appear important for empowering and informing communities of color.

Authors: Erica Weintraub Austin (1,2), Porismita Borah (1,2), Shawn Domgaard (3)

Affiliations: $(1,2)$ Edward R. Murrow Center for Media \& Health Promotion Research, Washington State University, USA, (3) Edward R. Murrow College of Communication, Washington State University, USA

How to cite: Austin, E. W., Borah, P., \& Domgaard, S. (2021). COVID-19 disinformation and political engagement among

communities of color: The role of media literacy. Harvard Kennedy School (HKS) Misinformation Review, 1(7).

Received: November 30th 2020 . Accepted: February $11^{\text {th }}, 2021$. Published: March $8^{\text {th }}, 2021$.

\section{Research questions}

- Will there be a difference in the media literacy and political belief scores between nonwhite and white respondents?

- Will there be a difference in the COVID-19 knowledge and COVID-19 disinformation belief scores between nonwhite and white respondents?

- To what extent will the ways media literacy associates with political behavior beliefs, COVID-19 knowledge, and COVID-19 disinformation beliefs differ for nonwhite respondents as compared to associations for white respondents?

\section{Essay summary}

- Communities of color, disproportionately affected by COVID-19 and equity gaps, also are inordinately targeted by disinformation campaigns. This study explored how media literacy might help protect individuals, particularly people of color, from believing COVID-19 disinformation and how it might promote political engagement.

- Results are drawn from a representative, national survey of U.S. adult residents $(N=1264)$ fielded

\footnotetext{
${ }^{1}$ A publication of the Shorenstein Center for Media, Politics and Public Policy, at Harvard University, John F. Kennedy School of Government.
} 
June 22-July 18, 2020, with demographic and regional quotas based on the 2019 U.S. census.

- Compared to white respondents, nonwhite respondents reported less media literacy, less intent to vote, more willingness to take risks to protest for racial justice (but not to reopen the economy), less COVID-19 knowledge, and more acceptance of COVID-19 disinformation.

- Respondents with more media literacy about news sources tended to support taking risks to protest, and those more literate about news sources and content had greater intentions to vote, but those with more science media literacy tended to express less support for taking risks to protest.

- Respondents with more science media literacy focused on critical thinking to interpret and integrate messages about scientific studies were less likely to believe COVID-19 disinformation.

- The results suggest that general and science-specific media literacy skills can be protective and empowering for communities of color.

\section{Implications}

Even before COVID-19, disinformation campaigns-purposefully shared false information employing principles of persuasion to deceive-presented risks during a pandemic (Larson, 2018) and spread falsehoods about election policies (Common Cause and Lawyer's Committee, 2012). COVID-19 disinformation then spread quickly in 2020 (Brennen, Simon, Howard \& Nielsen, 2020; Ishmael, 2020; WHO, 2020a). A lack of effective gatekeeping means that information consumers must determine what sources and content to believe (Bergstrom \& West, 2020; Linvill \& Warren, 2019; Starbird, Arif \& Wilson, 2019). This problem is magnified for people of color because disinformation campaigns often aim to impede their political participation. Meanwhile, accurate information often is poorly presented and unclear (Kim \& Kreps, 2020). It, therefore, is important to investigate tools that may help people mitigate an environment containing structural disadvantages, targeted disinformation strategies, and confusing public information.

This problem for communities of color is not new, although it worsened during the COVID-19 pandemic. For example, Black households received robocalls on election day 2010 suggesting that the governor's supporters could stay home because he already had won the election (Broadwater, 2011). Then, in 2017, heavily Black Jefferson County was targeted with text messages promoting false polling site changes (Morales-Doyle \& Frederick, 2018). A common strategy employs hashtags invoking Black Lives Matter or posing as Black activists to motivate sharing that magnifies disinformation (Linville \& Warren, 2019; Starbird, Arif, \& Wilson, 2019). These disinformation campaigns often promote election boycotts, attack mainstream candidates and promote third-party candidates. They also encourage tribalism to attack other groups (Diresta et al., 2018).

During the COVID-19 pandemic, Collins-Dexter (2020) identified four common COVID-19 disinformation themes targeting Black communities: Black people could not die from COVID-19; it was man-made to achieve population control; herbal remedies could contain it; and $5 \mathrm{G}$ radiation caused it. Also, during summer of 2020 , bots were used to amplify messages discouraging a Latinx boycott of Goya that followed statements from the company's CEO praising President Trump.

This study examined how media literacy skills may help reduce effects of disinformation campaigns, such as those occurring during the COVID-19 pandemic, to the extent they 1) contribute to rejecting disinformation and 2) contribute to political engagement for reducing opportunity gaps. Disinformation campaigns prey on people's uncertainty and emotional responses (Bergstrom \& West, 2020; Linvill \& Warren, 2019), but media literacy interventions can reduce disinformation's impact by strengthening critical thinking about sources and message content (Austin, Pinkleton \& Funabiki, 2007; Austin, Muldrow \& Austin, 2016; Austin, Austin, French, \& Cohen, 2018). Media literacy often is defined as the ability to 
access, analyze, evaluate and create media in a variety of forms (National Association for Media Literacy Education, 2007). It refers to critical thinking about media sources and content, including the meaning of stylistic characteristics, the content's accuracy and completeness, the source's implied values, and the context in which messages have been shared. Given the avalanche of COVID-19 disinformation circulating during 2020, this study also included media literacy measures specific to science- and health-related information.

This representative, national survey of U.S. adults, performed during the height of the pandemic and protests during early summer of 2020, found consistent differences between white and nonwhite participants for levels of media literacy, COVID-19 knowledge, acceptance of COVID-19 disinformation, levels of voting intent, and willingness to take risks to protest for racial justice. That people of color were less likely to vote but more willing to protest for social justice may reflect a desire to find alternative ways to advocate for civic change when institutional barriers dampen enthusiasm for voting (Lempinen, 2020). Respondents exhibiting more media literacy for news sources and content had stronger intentions to participate in political advocacy, knew more about COVID-19 and were less likely to believe COVID-19 disinformation campaigns. Overall, the findings of this study suggest that outreach to promote media literacy may provide a valuable tool.

The results support concerns that people of color tend to be inordinately affected by disinformation campaigns designed to impede or dissuade their participation in political engagement to improve their physical, societal, and economic health. They need especially strong skills to manage their responses to disinformation messages intentionally designed to provoke their emotions and promote social media sharing. Moreover, disinformation purveyors increasingly use fake outlets (Alba \& Nicas, 2020) and fake local hashtags (Starbird et al., 2019) to replace real, local journalism that is disappearing from communities, particularly those with less affluence (Abernathy, 2020).

The results also suggest that media literacy skills can be empowering despite systemic barriers to formal education and other resources. Given the evidence of equity gaps in effects of media on information gain and disinformation rejection, the potential for media literacy skills to help mitigate these gaps should be maximized. People of all ages need better access to information, such as how images need better access to information, such as how images and messages can be digitally altered to spread disinformation.

Future interventions to increase media literacy should include direct action on platforms where misinformation and disinformation may be prominent, with crowdsourcing offering a promising strategy for community-based interventions (Allen et al., 2020). Ashley Bryant of Win Black/Pa'lante, an advocacy group fighting disinformation on behalf of people of color, has noted "disinformation and voter suppression is a coordinated effort, and we have to meet that. We have to counter that with the same coordination" (Garcia-Navarro, 2020). Mobile interventions can make learning convenient, using popular platforms and messaging frames such as apps, games, memes, and tweets (FluTrackers, 2020; Go Viral Game, 2021; Helper, 2020). Brief messages can highlight fact-checking tools and reverse image searches (Tineye, 2021; WHO, 2020b; WHO, 2021). Coordination among advocacy groups can provide clearinghouses of age-appropriate materials for out-of-school learning and strengthen lobbying efforts for equal access to school-based media literacy education, in every state, that includes material about identity and difference (Celeste, 2019; Media Literacy Now, 2021). A variety of advocacy groups develop and share media literacy programming and lobby for policies. Some provide free and readily available resources (e.g., News Literacy Project, 2021), and some emphasize issues of identity, difference, and inclusion (Critical Media Project, 2021). 


\section{Findings}

Finding 1: As shown in Table 1 below, people of color tended to report less general and science-specific media literacy, lower levels of voting intent, and more willingness to take risks to protest for racial justice. This may reflect that when institutional barriers exist for making a difference through voting, people of color embrace other ways to advocate for change. They were not more likely to accept risks to protest for reopening the economy.

Finding 2: Also shown in Table 1, people of color tended to report more acceptance of COVID-19 disinformation and less accurate knowledge about COVID-19.

This is consistent with the evidence that disinformation campaigns targeting minorities in 2020 included many themes reflecting false information about COVID-19. This also aligns with concerns that accurate information has been lacking and inconsistent (Kim \& Kreps, 2020).

Table 1. t-tests comparing mean scores of white and nonwhite participants for key topics.

\begin{tabular}{|c|c|c|c|c|c|}
\hline & Group & $\mathrm{N}$ & Mean & $T$ & $d f$ \\
\hline \multirow{2}{*}{$\begin{array}{l}\text { Political Orientation (higher score is more } \\
\text { conservative) }\end{array}$} & NW & 617 & 2.85 & \multirow[t]{2}{*}{$-6.13^{* *}$} & \multirow[t]{2}{*}{1243.32} \\
\hline & W & 638 & 3.23 & & \\
\hline \multirow{2}{*}{ Age Group ( 1 younger-7 older) } & NW & 620 & 2.11 & \multirow[t]{2}{*}{$-10.50 * *$} & \multirow[t]{2}{*}{1243.21} \\
\hline & W & 641 & 2.98 & & \\
\hline \multirow{2}{*}{$\begin{array}{l}\text { Education (1-9; higher score reflects more } \\
\text { formal education) }\end{array}$} & NW & 616 & 4.10 & \multirow[t]{2}{*}{$-3.87^{* *}$} & \multirow[t]{2}{*}{1250.01} \\
\hline & W & 637 & 4.56 & & \\
\hline \multirow{2}{*}{$\begin{array}{l}\text { Income (1-9; higher score denotes more } \\
\text { income) }\end{array}$} & NW & 619 & 4.54 & \multirow[t]{2}{*}{$-5.41 * *$} & \multirow[t]{2}{*}{1254.35} \\
\hline & W & 638 & 5.17 & & \\
\hline \multirow{2}{*}{$\begin{array}{l}\text { Knowledge (higher score reflects more } \\
\text { knowledge) }\end{array}$} & NW & 621 & 4.07 & \multirow[t]{2}{*}{$-5.11 * * *$} & \multirow[t]{2}{*}{1254.35} \\
\hline & w & 643 & 4.65 & & \\
\hline \multirow{2}{*}{$\begin{array}{l}\text { COVID-19 disinformation beliefs (higher } \\
\text { score reflects more belief) }\end{array}$} & NW & 602 & 10.81 & \multirow[t]{2}{*}{$3.34 * *$} & \multirow[t]{2}{*}{1217.45} \\
\hline & w & 634 & 10.04 & & \\
\hline \multirow{2}{*}{$\begin{array}{l}\text { Media Literacy for Source (higher score is } \\
\text { better) }\end{array}$} & NW & 611 & 19.65 & \multirow[t]{2}{*}{$-5.19 * *$} & \multirow[t]{2}{*}{1231.49} \\
\hline & w & 629 & 21.35 & & \\
\hline \multirow{2}{*}{$\begin{array}{l}\text { Media Literacy for Content (higher score is } \\
\text { better) }\end{array}$} & NW & 600 & 17.58 & \multirow[t]{2}{*}{$-6.49 * *$} & \multirow[t]{2}{*}{1235} \\
\hline & W & 637 & 19.28 & & \\
\hline \multirow{2}{*}{$\begin{array}{l}\text { Science Media Literacy (higher score is } \\
\text { better) }\end{array}$} & NW & 578 & 2.47 & \multirow[t]{2}{*}{$-7.00^{* *}$} & \multirow[t]{2}{*}{1173.36} \\
\hline & $w$ & 610 & 3.27 & & \\
\hline \multirow{2}{*}{$\begin{array}{l}\text { Favor Taking Risks to Protest for Racial } \\
\text { justice (higher score is more approval) }\end{array}$} & NW & 618 & 2.82 & \multirow[t]{2}{*}{$3.77^{* *}$} & \multirow[t]{2}{*}{1256.04} \\
\hline & $w$ & 641 & 2.52 & & \\
\hline \multirow{2}{*}{$\begin{array}{l}\text { Favor Taking Risks to Protest for } \\
\text { Reopening the Economy (higher score is } \\
\text { more approval) }\end{array}$} & NW & 619 & 2.45 & \multirow[t]{2}{*}{1.50} & \multirow[t]{2}{*}{1252.07} \\
\hline & W & 637 & 2.33 & & \\
\hline \multirow{2}{*}{$\begin{array}{l}\text { Voting Intent (higher score is stronger } \\
\text { intent) }\end{array}$} & NW & 614 & 2.98 & $-7.72^{* *}$ & 1223.62 \\
\hline & w & 636 & 3.42 & & \\
\hline
\end{tabular}

Notes: $N W=n o n$ white; $W=$ white. Statistical significance denoted by ${ }^{*} p<.01 ; * *<.001 ;$ The only measures nonsignificant for Levene's test for equality of variances were Media Literacy for Content and COVID-19 disinformation Beliefs; this affects the choice of t-test used and degrees of freedom reported. 
Finding 3: As shown in Table 2 below, associations between media literacy and demographics were weak.

Demographics represent institutional opportunities and barriers, and long-standing discriminatory policies require sustained advocacy to remedy (Wilkerson, 2020; Rothstein, 2017). According to the National Science Foundation (2018), people with more education and income tend to know more about principles of scientific inquiry. Nevertheless, public understanding of science has increased over time regardless of education levels. This suggests that people also learn about science from informal sources, such as the media and one another. Thus, although growing equity gaps may affect the abilities for people of color to resist disinformation and mobilize for political action (Fain, 2020; Modan, 2020; Strada, 2020), they also may be affected by a sustained lack of minority representation in the media (Brooks \& Hebert, 2006; Dixon \& Linz, 2000; Sui \& Paul, 2017). In other words, because few states require and assess media literacy instruction in formal education, an unequal presence of community-based voices promoting critical thinking about media and circulating information could help explain equity gaps in media literacy (Media Literacy Now, 2020).

Table 2. Associations of demographics with media and science media literacy for white and nonwhite respondents.

\begin{tabular}{|c|c|c|c|c|c|c|c|c|c|}
\hline $\begin{array}{l}\text { Predicted } \\
\text { Measures }\end{array}$ & $\begin{array}{l}\text { Predictor } \\
\text { Measures }\end{array}$ & $\begin{array}{l}\text { Direction } \\
\text { and } \\
\text { Strength } \\
\text { of Std } \\
\text { Estimate }\end{array}$ & NONW & $d f$ & $A R^{s q}$ & $\begin{array}{l}\text { Direction } \\
\text { and } \\
\text { Strength } \\
\text { of Std } \\
\text { Estimate }\end{array}$ & WHIT & $d f$ & $A R^{s q}$ \\
\hline $\begin{array}{l}\text { dia Literacy } \\
\text { Source of } \\
\text { ws (higher } \\
\text { re is better) }\end{array}$ & $\begin{array}{l}\text { Education (1-9) } \\
\text { Income (1-9) }\end{array}$ & $\begin{array}{r}.10^{*} \\
--\end{array}$ & $\begin{array}{c}6.36 \\
--\end{array}$ & 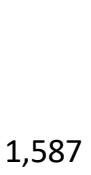 & $\begin{array}{c}.01 \\
--\end{array}$ & $\begin{array}{l}.18^{* * *} \\
.17^{* * *}\end{array}$ & $\begin{array}{l}49.84 \\
32.00\end{array}$ & 2,611 & $\begin{array}{l}.07 \\
.02\end{array}$ \\
\hline $\begin{array}{l}\text { dia Literacy } \\
\text { Content of } \\
\text { ws (higher } \\
\text { re is better) }\end{array}$ & $\begin{array}{l}\text { Education (1-9) } \\
\text { Income (1-9) } \\
\text { Income (1-9) }\end{array}$ & $\begin{array}{c}.08^{*} \\
--\end{array}$ & $\begin{array}{c}4.07 \\
--\end{array}$ & 1,576 & $\begin{array}{c}.01 \\
--\end{array}$ & $\begin{array}{l}.20^{* * *} \\
.14^{* *}\end{array}$ & $\begin{array}{l}51.48 \\
30.79\end{array}$ & 2,619 & $\begin{array}{l}.08 \\
.01\end{array}$ \\
\hline $\begin{array}{l}\text { ence Media } \\
\text { eracy (higher } \\
\text { re is better) }\end{array}$ & $\begin{array}{l}\text { Political } \\
\text { Orientation (1-5) } \\
\text { Income (1-9) } \\
\text { Age Group (1-7) } \\
\text { Population } \\
\text { Density } \\
\text { Education (1-9) }\end{array}$ & $\begin{array}{c}-.15^{* * *} \\
.12^{* *}\end{array}$ & $\begin{array}{l}11.18 \\
9.58\end{array}$ & 2,551 & $\begin{array}{l}.02 \\
.01\end{array}$ & $\begin{array}{c}-- \\
-- \\
.25 * * * \\
-.10^{*} \\
.09 *\end{array}$ & $\begin{array}{c}-- \\
-- \\
50.24 \\
27.66 \\
20.35\end{array}$ & 3,591 & $\begin{array}{l}-- \\
-- \\
.08 \\
.01 \\
.00\end{array}$ \\
\hline
\end{tabular}

Notes: $N W=$ nonwhite; $W=$ white. Statistical significance denoted by ${ }^{*} p<.05 ;{ }^{* *} p<.01 ;{ }^{* *} p<.001$; Gender coded as binary with higher score representing female. Stepwise entry of demographics. Degrees of freedom reported are for the final block of measures entering the equation.

Finding 4: As shown in Table 3, nonwhite participants higher on COVID-19 disinformation beliefs tended to be male, lower in science media literacy, and lower on media literacy for source after science media literacy was statistically controlled. 
Science media literacy was not associated with COVID-19 disinformation beliefs and was positively associated with science media literacy, $r=.23, p<.001$, in bivariate analysis. This small but significant relationship could reflect that, for evaluating COVID-19-specific disinformation themes, media literacy for source is not useful without a specific understanding of how to assess sources for science information.

White participants higher on COVID-19 disinformation beliefs tended to be more conservative, younger, less science media literate, more affluent, and more educated. Cross-sectional survey data cannot determine why higher income and more education would associate with COVID-19 disinformation beliefs for white respondents, but it is possible that informal education about media literacy is lacking among some privileged communities. Overall, respondents more knowledgeable about COVID-19 tended to be more science media literate and more media literate for content. White respondents with more COVID-19 knowledge also tended to be older.

Nonwhite respondents likely to approve of taking risks to protest for racial justice tended to be younger, more educated, and less science media literate but more media literate for sources. White respondents likely to approve tended to be less science media literate and more educated, older, more liberal, and more affluent. Less science-literate nonwhite respondents who approve of taking risks to protest for racial justice may be motivated by sources and issues they deem credible regarding political advocacy, while more science-literate individuals also factor in the safety risks of this action into their decision-making.

Nonwhite respondents who approved of taking risks to protest for reopening the economy tended to be more educated, male, less science media literate, and more media literate about sources. White respondents likely to approve were similar for gender, science media literacy, and media literacy for source, and they tended to be younger and more affluent. These findings may reflect how structural inequalities and economic realities combine to affect political advocacy.

Nonwhite participants with intention to vote in the November election tended to be more highly educated and more media literate both for sources and for content. White respondents willing to vote also tended to be more media literate for sources and for content but were not more highly educated and tended to be older, of higher income, and with more science media literacy. It should be noted that the measure of voting intent was limited-a single measure rather than a multi-item set that included previous behavior. Responses skewed heavily toward enthusiasm for voting, so even the modest associations found with media literacy measures could represent an important clue for motivating participation. Again, demographics were weakly associated with voting intent compared to voting intent's associations with media literacy.

In general, associations found in the data tended to be weaker for nonwhite participants. This could reflect a lack of cultural responsiveness in the measures that could be explored through research methods such as focus groups and interviews. It also is possible that the survey questions did not adequately reflect the lived experience of nonwhite respondents and that mixed-method research approaches may provide richer explanations regarding their consumption and interpretations of media content.

These results highlight the importance of assessing media literacy skills that are relevant to specific contexts in addition to skills relevant to more general assessments of news and information. Although science media literacy had a moderate relationship with media literacy for source $(r=.20, p<.001)$ and media literacy for content $(r=.26, p<.001)$, they were not perfectly aligned. Specific skills important for assessing science-related information might be missing from people's understanding of media literacy more generally. The measures in this study for general media were self-assessments, whereas the measures for science media literacy required actual knowledge about the meaning of science reporting concepts such as correlation, random assignment, and the differential quality of publication outlets. 
Table 3. Media literacy and demographic associations with political engagement for white and nonwhite respondents. NONWHITE

Direction

$$
\text { and }
$$

Predicted

Measures

Predictor Measures

Strength of

Std

Estimate

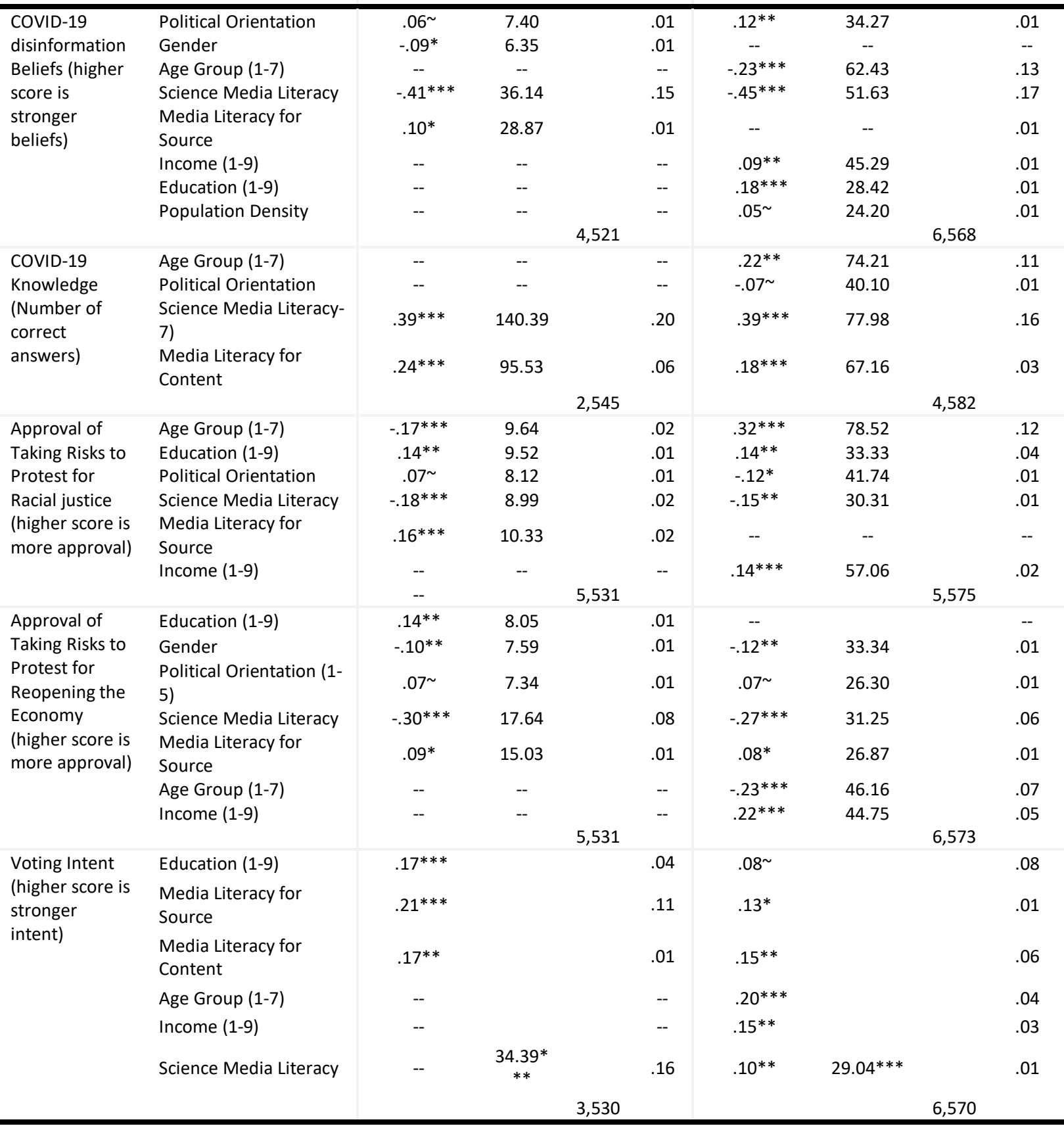

Notes: Stepwise entry of demographics followed by stepwise entry of other independent measures. ns after other measures enter the equation; NW=non white; $W=$ white. Statistical significance denoted by ${ }^{*} p<.05 ;{ }^{* *} p<.01 ;{ }^{* * *} p<.001 ;$ Gender coded as binary with higher score representing female. Degrees of freedom reported are for the final block of measures entering the equation. 


\section{Methods}

This study investigated how media literacy is associated with political behavior beliefs, COVID-19 knowledge, and COVID-19 disinformation beliefs for nonwhite U.S. respondents compared to U.S. white respondents. Disinformation targeting communities of color is an ongoing problem that became even worse in the context of the 2020 elections taking place during the COVID-19 crisis (Timberg \& StanleyBecker, 2020). A combination of general and science-specific measures for media literacy, political engagement, and the specific situation of the COVID-19 crisis provided an opportunity to examine relationships between media literacy and the effects of COVID-19 disinformation campaigns.

\section{Data collection}

A representative, national survey of U.S. adult residents $(N=1264)$ was fielded through Qualtrics June 22July 18 , at the height of lockdown and social-justice demonstrations. The survey included $76.4 \%$ participants from urban zip codes, near to actual rural/urban distribution in the U.S. Census (United States Census Bureau, 2019). The sample included demographic and regional quotas based on the 2019 U.S. census. Panel-based sampling with quality check measures is a preferred strategy because response rates to phone surveys have plunged as low as 4-6\% (Pew Research Center, 2018). Quality check measures eliminated duplicate, illogical, and improbably fast completions. Post-stratified sample weights ensured subsamples from each of four U.S. regions reflected census estimates (Lee \& Forthofer, 2006; United States Census Bureau, 2019). Respondents could indicate multiple ethnicities and were coded as white if no other ethnicities were indicated.

The questions asked of participants, shown in Table 4, were adapted from previous studies and tested for readability, with the exception of science media literacy, created for this study based on previously published definitions (Fives, Huebner, Birbaum \& Nicolich, 2014) and Kalaichandran's (2020) list of tips to aid readers trying to assess the quality of research studies they read. CFAs and Cronbach's alpha confirmed reliability for summed scores of measures for Media Literacy for Source $(\alpha=.90)$ and for Content $(\alpha=.88)$ of News (Austin et al., 2016); science media literacy ( $\alpha=.69$ ); and COVID-19 disinformation beliefs ( $\alpha=.82$ ), updated from previous research on disinformation (e.g., Bode \& Vraga, 2018), to reflect COVID-19 disinformation messages in early 2020 that had gone viral (Brennen et al., 2020; Johns Hopkins Medicine, 2020; Medical News Today, 2020). Measures also included intentions to vote ("I plan to vote in the November 2020 US election," 1 definitely not to 4 definitely yes); approval of taking risks ("It is worth risking my health to join a public demonstration....to protest for racial justice" or "...to reopen the economy," on 5-point scales); and demographics of age, education, ethnicity, gender identity, income, political orientation, and population density. Disinformation beliefs are the acceptance of intentionally shared false information themes that are developed using principles of persuasion. This is different from believing misinformation, which is innocently spread, inaccurate information that can result from confusing or incomplete information sharing. Potential misinformation beliefs, such as that antibiotics can cure a virus, were included in the COVID-19 knowledge measures.

\section{Data analysis}

Following data collection, statistical procedures of factor analysis and computation of Cronbach's alpha were used to eliminate COVID-19 disinformation items that associated comparatively weakly with the others. Eliminated items included, for example, the belief that people were contracting COVID-19 from food or packaging from grocery stores. 
COVID-19 knowledge items included common misperceptions that might be linked to confusion, evolving information, and mixed messages rather than to deliberately spread COVID-19 disinformation. Factor analysis and reliability analysis were used to verify that these items were most appropriately considered as separate from the COVID-19 disinformation items. For example, the use of garlic in some naturopathy traditions could lead to the belief that garlic could cure the virus, and some people get confused about the relevance of antibiotics for curing a virus. Knowledge items were drawn from information from the World Health Organization (2020), the Centers for Disease Control (2020b), and a contemporary RTI (2020) survey. Because knowledge and science media literacy were based on what individuals believed to be true, the variable was coded to represent "knowledge" or "a lack of knowledge." The total score represented the number of correct responses to the questions. A response that represented an incorrect answer or an acknowledgment of uncertainty was coded as "a lack of knowledge."

Measures for media literacy for sources of news and media literacy for content of news were based on previous studies that have used these measures to represent self-reported media literacy skills. This study did not collect performance-based data about general media literacy skills, such as by having respondents do a message deconstruction exercise.

Table 4. Measures for study topics.

Topics and measures

Description

Media Literacy for News Sources

1=Strongly Disagree-

- I think about how someone creates news that I see. 5=Strongly Agree

- I think about who created the news I am seeing.

- I think about what the creator of the news message wants me to think.

- I think about what the creator of the news I am seeing is trying to accomplish.

- I compare news information from different media sources.

- I check to see if the original source of information I see in the news is clearly stated.

\section{Media Literacy for News Content}

- I compare new information I see in news with other information I have seen before I accept it as believable.

- I look for more information before I believe something I see in news.

- It is important to think twice about what news messages say.

- I often consider whether a message in news is accurate.

- I check on whether information I see in the news is up to date.

\section{Science Media Literacy}

- If two things are related, or correlated, it means that one caused the other.

- If a medication works well in animals, it will always work well in humans too.

- Research that randomizes people, animals, or plants to conditions and examines effects of a treatment in a controlled

\section{1=Strongly Disagree- $5=$ Strongly Agree}


environment (randomized controlled trials) are often of higher quality than research that looks at associations.

- If a medication or treatment works for one group of people, it will work for all people.

- One scientific study often shifts an entire course of medical practice or public policy.

- All journals that publish research are equally credible.

- Scientific findings from the lab can be assumed to work the same way in the real world

\section{COVID-19 Disinformation Beliefs}

- Hand dryers kill COVID-19.

- 5 G radiation is the real cause of COVID-19.

- The new Coronavirus was deliberately created or released by people.

- You can protect yourself from COVID-19 by injecting, swallowing, bathing in or rubbing onto your body bleach, disinfectants or rubbing alcohols.

\section{Knowledge}

- Antibiotics can be used to treat the COVID-19 virus $1=$ True, $0=$ False, $0=$ Don't Know*

- People of all ages can become infected with COVID-19

- People of all racial and ethnic groups can become infected with COVID-19

- Eating garlic can lower your chances of getting infected with the COVID-19 virus

- Most people who are infected with the COVID-19 virus die from it

- Most people who are infected with the COVID-19 virus recover from it

- Older adults or those with compromised immune systems are at a higher risk

* The total score represented the number of correct responses to the questions. An incorrect answer or an acknowledgment of uncertainty was coded as a lack of knowledge.

\section{Bibliography}

Abernathy, P. M. (2020). News deserts and ghost newspapers: Will local news survive? Center for Innovation and Sustainability in Local Media, School of Media and Journalism, University of North Carolina at Chapel Hill. https://www.usnewsdeserts.com/wpcontent/uploads/2020/06/2020 News Deserts and Ghost Newspapers.pdf

Alba, D. \& Nicas, J. (2020, October 20). As local news dies, a pay-for-play network rises in its place. The New York Times. https://www.nytimes.com/2020/10/18/technology/timpone-local-newsmetric-media.html 
Allen, J., Arechar, A. A., Pennycook, G., \& Rand, D. G. (2020). Scaling up fact-checking using the wisdom of crowds. PsyArXiv. https://doi.org/10.31234/osf.io/9qdza

Austin, E. W., Austin, B. W., \& Kaiser, C. K. (2020). Effects of family-centered media literacy training on family nutrition outcomes. Prevention Science, 21(3), 308-318. https://doi.org/10.1007/s11121$\underline{020-01101-x}$

Austin, E. W., Austin, B. W., French, B. F., \& Cohen, M. A. (2018). The effects of a nutrition media literacy intervention on parents' and youths' communication about food. Journal of Health Communication, 23(2), 190-199. https://doi.org/10.1080/10810730.2018.1423649

Austin, E. W., Muldrow, A., \& Austin, B. W. (2016). Examining how media literacy and personality factors predict skepticism toward alcohol advertising. Journal of Health Communication, 21(5), 600-609. https://doi.org/10.1080/10810730.2016.1153761

Austin, E. W., Pinkleton, B. E., \& Funabiki, R. P. (2007). The desirability paradox in the effects of media literacy training. Communication Research, 34(5), 483-506. https://doi.org/10.1177/0093650207305233

Bergstrom, C. T., \& West, J. D. (2020). Calling bullshit: The art of skepticism in a data-driven world. Random House. https://doi.org/10.1126/science.abd9788

Bode, L., \& Vraga, E. K. (2018). See something, say something: correction of global health misinformation on social media. Health Communication, 33(9), 1131-1140.

Brennen, J. S., Simon, F., Howard, P. N., \& Nielsen, R. K. (2020, April 7). Types, sources, and claims of COVID-19 misinformation. Reuters Institute. https://reutersinstitute.politics.ox.ac.uk/typessources-and-claims-covid-19-misinformation

Broadwater, L. (2011, November 29). Prosecutors: GOP 'robocall' plan to suppress black votes hatched on hectic election day. The Baltimore Sun. https://www.baltimoresun.com/politics/bs-mdshurick-trial-20111129-story.html

Brooks, D. E., \& Hébert, L. P. (2006). Gender, race, and media representation. Handbook of Gender and Communication, 16, 297-317. https://doi.org/10.4135/9781412976053.n16

Celeste, M. (2019, December 16). Teach them well: Media literacy as a survival tool for marginalized youth. Spark. https://medium.com/national-center-for-institutional-diversity/teach-them-wellmedia-literacy-as-a-survival-tool-for-marginalized-youth-207322e3cd44

Chavez, N. (2020). 'There's no such thing as the Latino vote.' 2020 results reveal a complex electorate. CNN. https://www.cnn.com/2020/11/09/politics/latino-voters-florida-texas-arizona/index.html

Collins-Dexter, B. (2020). Canaries in the coal mine: COVID-19 misinformation and black communities. Harvard Kennedy School Shorenstein Center. https://doi.org/10.37016/TASC-2020-01

Common Cause and Lawyer's Committee. (2012). Deceptive election practices and voter intimidation: The need for voter protection. https://lawyerscommittee.org/wpcontent/uploads/2015/07/DeceptivePracticesReportJuly2012FINALpdf.pdf

Critical Media Project. (2021). Why identity matters. https://criticalmediaproject.org/why-identitymatters/

DiResta, R., Shaffer, K., Ruppel, B., Sullivan, D., Matney, R., Fox, R., Albright, A., Johnson, B. (2018, December 18). The tactics \& tropes of the Internet Research Agency. Report to the United States Senate. https://disinformationreport.blob.core.windows.net/disinformationreport/NewKnowledge-Disinformation-Report-Whitepaper.pdf

Dixon, T. L., \& Linz, D. (2000). Overrepresentation and underrepresentation of African Americans and Latinos as lawbreakers on television news. Journal of Communication, 50(2), 131-154. https://doi.org/10.1111/j.1460-2466.2000.tb02845.x 
Fain, P. (2020, June 17). Higher education and work amid crisis. Inside Higher Ed. https://www.insidehighered.com/news/2020/06/17/pandemic-has-worsened-equity-gapshigher-education-and-work

Fives, H., Huebner, W., Birnbaum, A. S., \& Nicolich, M. (2014). Developing a measure of scientific literacy for middle school students. Science Education, 98(4), 549-580. https://doi.org/10.1002/sce. 21115

FluTrackers.com [@Flutrackers]. (2020, July 30). We will not know real death numbers until there is an analysis of excess deaths year-over-year. It is poss that [Tweet]. Twitter. https://twitter.com/FluTrackers/status/1288975841100271616

Freelon, D., Bossetta, M., Wells, C., Lukito, J., Xia, Y., \& Adams, K. (2020). Black trolls matter: Racial and ideological asymmetries in social media disinformation. Social Science Computer Review. https://doi.org/10.1177/0894439320914853

Garcia-Navarro, L. (2020, October 18). Progressive group combats disinformation campaigns aimed at Latino voters. National Public Radio. https://www.npr.org/2020/10/18/925069823/progressivegroup-combats-disinformation-campaigns-aimed-at-latino-voters

Go Viral Game. (2021). Go Viral! A 5-minute game that helps protect you against COVID-19 misinformation. https://www.goviralgame.com/en?utm source=EO\&utm medium=SocialMedia \&utm campaign=goviral\&utm content=Eng

Helper, E. (2020, August 6). A 'war room' that arms Black and Latino voters against disinformation. Los Angeles Times. https://www.latimes.com/politics/story/2020-08-06/war-room-arms-blacklatino-voters-against-disinformation

Ishmael, A. (2020, May 18). 'Plandemic' recirculates after platforms say they took it down. Poynter. https://www.poynter.org/fact-checking/2020/plandemic-recirculates-after-platforms-say-theytook-it-down/

Johns Hopkins Medicine. (2020, April 27). Coronavirus disease 2019: Myth vs. fact. https://www.hopkinsmedicine.org/health/conditions-and-diseases/coronavirus/2019-novelcoronavirus-myth-versus-fact

Jones, J. M. (2020, May 7). Attitudes about local news mostly stable amid COVID-19. Gallup. https://news.gallup.com/poll/310013/attitudes-local-news-mostly-stable-amid-covid.aspx

Kalaichandran, A. (2020, April 17). Worried about that new medical study? Read this first. The New York Times. https://www.nytimes.com/2020/04/17/parenting/medical-study-concerns.html

Kim, D. K \& Kreps, G. L. (2020). An analysis of government communication in the United States during the COVID-19 pandemic: Recommendations for effective government health risk communication. World Medical \& Health Policy, 12(4), 398-412. https://doi.org/10.1002/wmh3.363

Koonce, J. (2017). The roles of digital literacies and critical literacy for black adolescent females. Journal of Literacy and Technology, 18(1), 80-104. http://www.literacyandtechnology.org/uploads/1/3/6/8/136889/jlt v18 1 koonce.pdf

Larson, H.J. (2018). The biggest pandemic risk? Viral misinformation. Nature, 562(7726), 309. https://go.gale.com/ps/anonymous?id=GALE\%7CA573035610\&sid=googleScholar\&v=2.1\&it=r\&l inkaccess $=a b s \& i s s n=00280836 \& p=A O N E \& s w=w$

Lee, E. S., \& Forthofer, R. N. (2006). Analyzing complex survey data. Sage. https://doi.org/10.4135/9781412983341

Lempinen, E. (2020, September 29). Stacking the deck: How the GOP works to suppress minority voting. Berkeley News. https://news.berkeley.edu/2020/09/29/stacking-the-deck-how-the-gop-worksto-suppress-minority-voting/ 
Linvill, D., \& Warren, P. (2019). That uplifting tweet you just shared? A Russian troll sent it. Rolling Stone. https://www.rollingstone.com/politics/politics-features/russia-troll-2020-election-interferencetwitter-916482/

Media Literacy Now. (2020). U.S. media literacy policy report 2020. https://medialiteracynow.org/wpcontent/uploads/2020/01/U.S.-Media-Literacy-Policy-Report-2020.pdf

Media Literacy Now. (2021). Putting media literacy on the public policy agenda. https://medialiteracynow.org/your-state-legislation/

Medical News Today. (2020). Coronavirus myths explored. https://www.medicalnewstoday.com/articles/coronavirus-myths-explored

Modan, N., (2020, June 18). Amid concerns of widening equity gaps, Black educators suggest a starting point. Education Dive. https://www.educationdive.com/news/amid-concerns-of-wideningequity-gaps-black-educators-suggest-a-starting-p/579924/

Morales-Doyle, S., \& Frederick, S. (2018, August 8). Intentionally deceiving voters should be a crime. The Hill. https://thehill.com/opinion/civil-rights/400941-intentionally-deceiving-voters-should-be-acrime

National Association for Media Literacy Education. (2007, November). The core principles of media literacy education. https://namle.net/publications/core-principles/

National Science Board. (2018). Public knowledge about S\&T in Science and technology: Public attitudes and understanding. https://www.nsf.gov/statistics/2018/nsb20181/report/sections/scienceand-technology-public-attitudes-and-understanding/public-knowledge-about-s-t

News Literacy Project. (2021). For everyone. https://newslit.org/for-everyone/

Owusu, S. (2010, February 15). Using media literacy to combat racism. Youth Media Reporter. http://www.youthmediareporter.org/2010/02/15/using-media-literacy-to-combat-racism/

Pew Research Center. (2018, October 9). Comparing survey sampling strategies: Random-digit dial vs. voter files. https://www.pewresearch.org/methods/2018/10/09/performance-of-the-samples/

Scharrer, E. \& Ramasubramanian, S. (2015). Intervening in the media's influence on stereotypes of race and ethnicity: The role of media literacy education. Journal of Social Issues, 71(1), 171-185. https://doi.org/10.1111/josi.12103

Squires, G. D. (2017). The color of law: A forgotten history of how our government segregated America. Kalfou, 4(2), 325-329. https://doi.org/10.15367/kf.v4i2.171

Starbird, K., Arif, A., \& Wilson, T. (2019). Disinformation as collaborative work: Surfacing the participatory nature of strategic information operations. Proceedings of the ACM on HumanComputer Interaction, 3(CSCW), 1-26. https://doi.org/10.1145/3359229

Strada Education Network. (2020). Public viewpoint: COVID-19 work and education survey. https://www.stradaeducation.org/publicviewpoint/

Sui, M., \& Paul, N. (2017). Latino portrayals in local news media: Underrepresentation, negative stereotypes, and institutional predictors of coverage. Journal of Intercultural Communication Research, 46(3), 273-294. https://doi.org/10.1080/17475759.2017.1322124

Timberg, C., \& Stanley-Becker, I. (2020, August 26). Black voters are being targeted in disinformation campaigns, echoing the 2016 Russian playbook. The Washington Post. https://www.washingtonpost.com/technology/2020/08/26/race-divisions-highlighteddisinformation-2016/

TinEye. (2021). Reverse image search. https://tineye.com/

United States Census Bureau. (2019, December 30). State population totals and components of change: 2010-2019. https://www.census.gov/data/tables/time-series/demo/popest/2010s-statetotal.html

Wilkerson, I. (2020). Caste: The origins of our discontents. Random House. 
World Health Organization. (2020a, September 23). Managing the COVID-19 infodemic: Promoting healthy behaviours and mitigating the harm from misinformation and disinformation. https://www.who.int/news/item/23-09-2020-managing-the-covid-19-infodemic-promotinghealthy-behaviours-and-mitigating-the-harm-from-misinformation-and-disinformation

World Health Organization. (2020b, November 23). Coronavirus disease (COVID-19) advice for the public: Mythbusters. https://www.who.int/emergencies/diseases/novel-coronavirus2019/advice-for-public/myth-busters

World Health Organization. (2021). How to report misinformation online. https://www.who.int/campaigns/connecting-the-world-to-combat-coronavirus/how-toreport-misinformation-online 


\section{Funding}

This study did not receive outside funding from any external entities, such as agencies, industry or foundations.

\section{Competing interests}

The authors do not have any potential conflicts of interest.

\section{Ethics}

Study procedures were declared exempt by the University's Institutional Review Board, protocol \#18213. The sample included demographic and regional quotas based on the 2019 U.S. census. The survey included an informed consent procedure that had to be completed prior to answering survey questions.

The sample included demographic and regional quotas recruited by Qualtrics based on the 2019 U.S. census and reviewed by the first author. Ethnicity and gender categories were provided in the survey with the option to choose multiple categories and write in self-identified categories. Only male and female gender identities were employed in the analyses, as a binary measure. Nonbinary or self-described gender were options for respondents, but were indicated by $2 \%$ of the sample, insufficient for reliable use in the analyses. Hispanic/Latinx respondents who indicated additional ethnicities were coded by Qualtrics as Hispanic/Latinx unless Native American. Respondents coded as Asian included those who also indicated African American. Native American respondents with other ethnicities were coded as Native American. The sample representation thus provided the following groups for analysis: 98 Asian respondents (7.8\%); 227 Black respondents (18.0\%); 301 Hispanic/Latinx respondents (23.8\%); 592 white respondents (46.8\%); and 46 Native American/Alaskan Native/Pacific Islander/Native Hawaiian respondents (3.6\%).

Gender identity and race/ethnicity were used in the analyses because the study endeavored to explain the role of media literacy beyond demographic categories typically employed to represent system-level manifestations of equity, access and privilege.

\section{Copyright}

This is an open access article distributed under the terms of the Creative Commons Attribution License, which permits unrestricted use, distribution, and reproduction in any medium, provided that the original author and source are properly credited.

\section{Data Availability}

All materials needed to replicate this study are available via the Harvard Dataverse: https://doi.org/10.7910/DVN/8DEYWD 